ISSN 1014-4874

DOI : http://dx.doi.org/10.4314/rj.v27i1.4

\title{
Climate Change and Hydropower Challenges In Southern Africa
}

\author{
J. P. M. Mulumba ${ }^{1}$, T. J. O. Afullo ${ }^{2}$ and N. Ijumba ${ }^{3}$
}

1. Lecturer, School of Environmental Science, University of Kwazulu Natal, Durban, South Africa (jpfuamba62@yahoo.fr)

2. Associate Professor, School of Electrical, Electronic and Computer Engineering, University of Kwazulu Natal, Durban, South Africa (afullot@ukzn.ac.za).

3 Ijumba, Nerson, DVC (Research), Professor of High Voltage Engineering, University of Kwazulu Natal, Durban, South Africa (DVCResearch@ukzn.ac.za).

\begin{abstract}
The purpose of this study is to address climate change impacts that challenge hydropower production and distribution in southern Africa. Change in temperature and precipitations due to climate change will affect rivers catchments runoff as well as hydropower dams and transmission lines in southern Africa. Evidences of these changes are being experienced on hydropower line failure in a few parts of the sub region. Since hydropower constitutes a clean and reliable energy, Africa has an imperious obligation to maximize its production and distribution in order to satisfy the increasing demand, and therefore meet the millennium development goals. Data and information from previous works undertaken on this topic have been compiled. Analysis and discussion of available information have been carried out through environmental perspective and scientific knowledge underpinning climate change and its impacts on the global geosphere and biosphere. Although increase in precipitations could be profitable to hydropower by more running water availability, extreme events including flood, siltration and strong winds, coupled with flashover (effect due to high concentration of air pollutants in ambient air), could raise the probability to see hydropower system being dramatically affected. The lowering of catchment capacity due to a large amount of sediments accumulation and the decline in energy generation by lack of sufficient water runoff are foreseeable problems. Thus a quick move towards adaptation measures as well as their effective implementation would constitute a significant benchmark for the maximization of hydropower generation capacity and consequently satisfying the ever growing energy demand for sustainable economic development in southern Africa.
\end{abstract}

Keywords: hydropower, climate change, challenges, adaptation measures

\section{Introduction}

In recent days much concern has been raised on climate change impacts on hydropower generation. Africa at large and southern Africa in particular, will be the most affected part of the world since adaptation and mitigating measures are lacking [IPCC, 2001]. In fact, the rising temperature as well as 
precipitation change constitutes two key factors that are likely to cause serious impacts on hydropower in Africa due to poor rivers and hydropower facilities management [Whittington and Gundry, 1998].

Although southern Africa is endowed with enormous hydropower potential which is sufficient to meet electricity needs of the continent, only a small fraction is exploited [Anonymous (a) 2008]. Since hydropower constitutes a clean and reliable energy [Whittington and Gundry, 1998; Harrison et al. 2000; $A P F, 2007]$ Africa has an imperious obligation to maximizing its production and distribution in order to satisfy the increasing demand, and therefore meet the millennium development goals [APF, 2007; Anonymous (a) 2008, Anonymous 2011]. In this regard, several calls in favour of regional interconnection have particularly been made in southern African countries in order to meet the socio economic development needs through industrialization [Mlambo-Ngcuka 2003, Mukheibir, 2007].

Inga dam in the Democratic Republic of Congo (DRC) and Cahora Bassa dam in Mozambique are the biggest power pools located in the southern African region. Not much information exists regarding these hydropower pool challenges with regard to climate change. However a few studies undertaken to assess climate change impacts on hydropower in the world reveal a $1.4-5^{\circ} \mathrm{C}$ temperature rise with an expected increase in global precipitation levels by $5-20 \%$ by the end of the next century, depending on regions [Harrison et. Al. 2000; Atushi, 2007]. These climatic changes could cause different threats to hydropower production and distribution especially in southern Africa where climate change impacts have already been experienced in Kenya and Tanzania in 2000 [Mukheibir, 2007], and recently [July-August 2011] in the DRC [Le potential, 2011]. Nonetheless climate change models undertaken by Intergovernmental Panel for Climate Change (IPCC) indicate minimum changes in the hydrology of the Congo basin whereas other basins in the region expect significant vulnerability to climate change [IPCC, 2001].

Despite the huge hydropower potential available in the subcontinent, energy efficiency needs for a sustainable development of the region necessitate good management scheme of hydropower resources. This implies strategic overseeing of the development of other clean energy sources such as wind, solar and biofuel energy $[A P F, 2007]$. In this paper we examine climate change impacts that are likely to affect hydropower production and distribution in southern Africa. We propose some adaptation and mitigation measures for hydropower sustainable production and management as well as alternative route for green energy production. 


\section{Methodology}

The methodology used to achieve the purpose of this work consists of data and information collection from previous works undertaken on this topic worldwide. Data from palaeoclimate science as well as various climate change models from different scientific forum have constituted our dataset for analysis and discussion. Universal model such as Milankovitch cycle have been used to provide better understanding of natural climate variations over time.

Feedback mechanisms on global climate have been used to extrapolate present and near future climate change and eventually their impacts on hydropower on tropical and subtropical African regions. Recent cases study and models describing hydrologic behavior and trends on hydropower sources such as rivers, dams and catchment through precipitation patterns have also been taken into account to comprehend hydrographic change processes.

Analysis and discussion of the available information have been cross examined based on the environmental perspective with regard to our knowledge on climate change and its impacts on the global geosphere and biosphere.

\section{Natural Causes of Climate Change}

\section{Astronomical factors.}

Climate change cannot be longer considered as a recent event. There are evidences that variations in solar energy input are the cause of long term climate change [Hays et al.1976]. Over thousands of years, changes occur in the earth's orbit around the sun and cause subsequent variations in the strength of solar radiation reaching the earth [Tyson and Preston-white, 2000]. These changes known as Milanchovich cycles include the eccentricity of the earth's orbit, the obliquity of the ecliptic (varying from 21.8 to $24.4^{\circ}$ over 24.000 year period) and the procession of the equinoxes known as aphelion and perihelion [Hays et al.1976; Tyson and Prestonwhite, 2000].

\section{The variation in solar output}

Although the variation in solar output is still one of the enduring unanswered meteorological questions [Tyson and Preston-White, 2000], there is evidence that long term variations of solar constant may contribute to natural change [Feldman 1993]. 


\section{Volcanic eruptions}

Emission of aerosols and greenhouse gases such as carbon dioxide and sulfur dioxide, can impact on climate change by cooling or warning [Robock and Oppenheimer, 2003]. In this regard, a study on global warming done by Free and Robock [1999] confirmed that the major causes of climate change from 1600 to 1850 were natural, with volcanic eruptions being the most important.

\section{Anthropogenic Causes of Climate Change}

There are various evidences that greenhouse gas emission from human activities [industries, transportation, agriculture and forestry, biomass burning, waste disposal and treatment, etc.] contribute to climate change.

In the past century, anthropogenic emission of greenhouse gases $\left[\mathrm{CO}_{2}\right.$, $\mathrm{SO}_{2}, \mathrm{NO}_{2}$, etc] has contributed to the 0.6 $\pm 0.2^{\circ} \mathrm{C}$ warming [Jones et al., 1999; Folland et al. 2001]. However Houghton et al. [2001] confirm that most of the warming of the second half of the 20th century was caused by human pollution of the atmosphere.

Figure 1 illustrates anthropogenic emissions in carbon dioxide which almost represents the third of anthropogenic activities originating from fossil fuel (57\%) and the rest being partitioned between carbon dioxide from deforestation, methane and other greenhouse gases, [IPCC 2007].

Figure 2 shows that energy supplies occupy the biggest share $(25.9 \%)$ of the

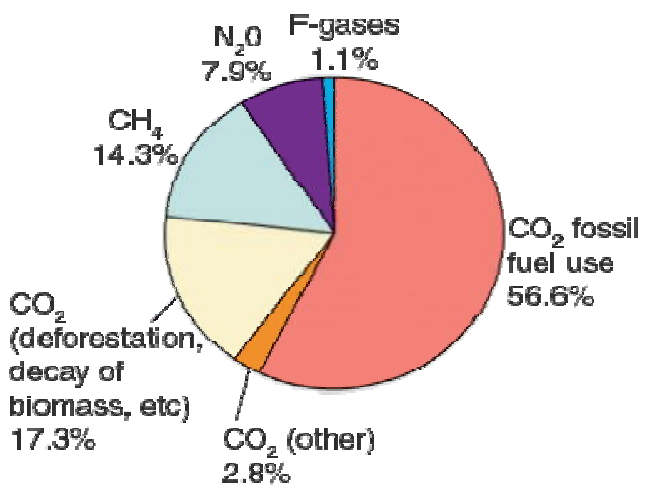

Figure 1 : Global anthropogenic greenhouse emissions by gas.

Source: IPCC 4th Assessment Report (2007)

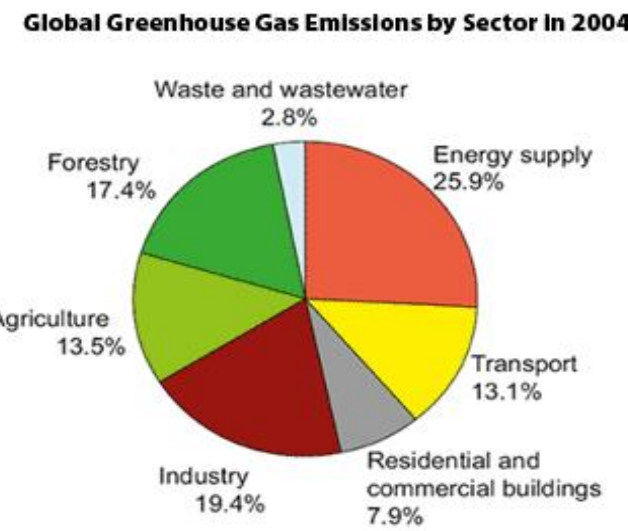

Figure 2: Global anthropogenic greenhouse gas emissions by sector (2004) Source: IPCC 4th Assessment Report (2007). 
anthropogenic emission, followed by industries (19.4\%) and forestry and agriculture (17.4\% and $13.5 \%)$. Transport sector as well as residential and waste and water treatment contribute respectively $13.1 \%, 7.9 \%$, and $2.8 \%$.

\section{Current Climate Change Evidences}

The dramatic increase on carbon dioxide in the free atmosphere since the industrial revolution that started in Europe and in northern America in the 1950s is displayed in Figure 3 [http://climate.nasa.gov/evidence]. Sea level rise, the global increase in temperature and the shrinking of ice sheets in the northern and southern poles constitute evidences that confirm the current climate change trends.

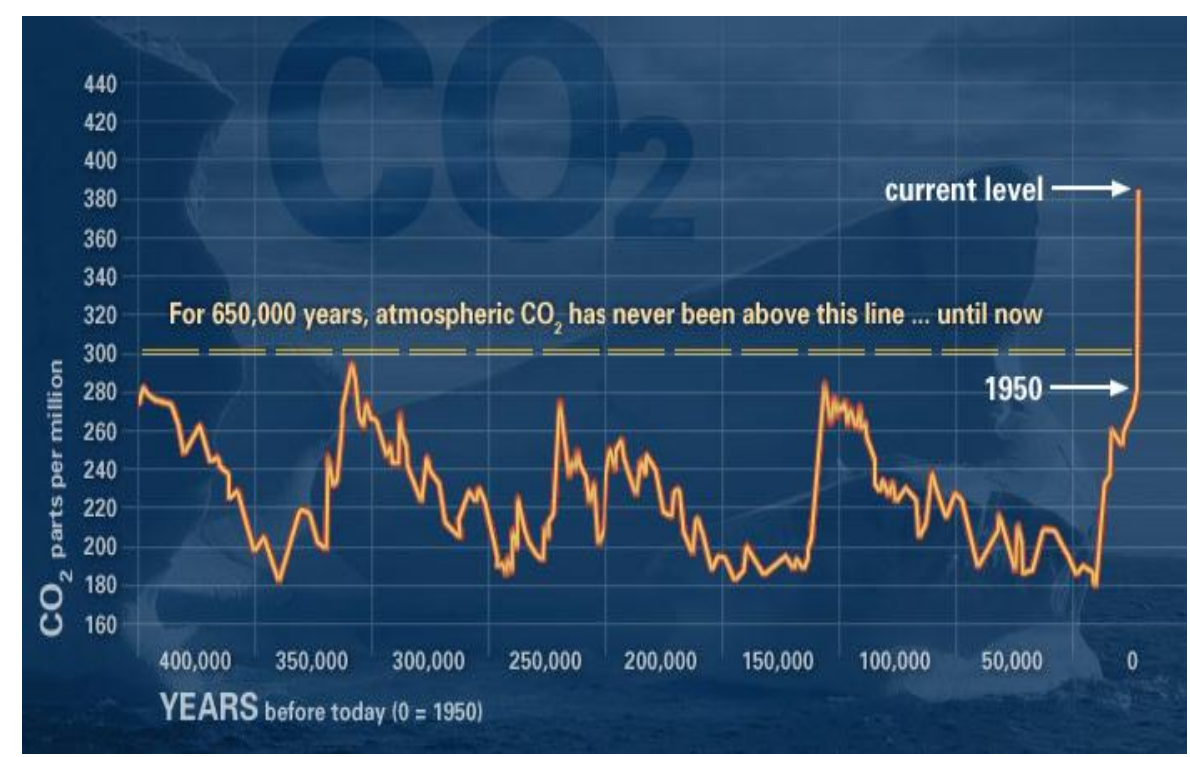

Figure 3 : Comparison of atmospheric samples contained in ice cores and more recent direct measurements, provides evidence that atmospheric carbon dioxide has increased since the Industrial Revolution. (Source: NOAA) http:// climate.nasa.gov/evidence/ 


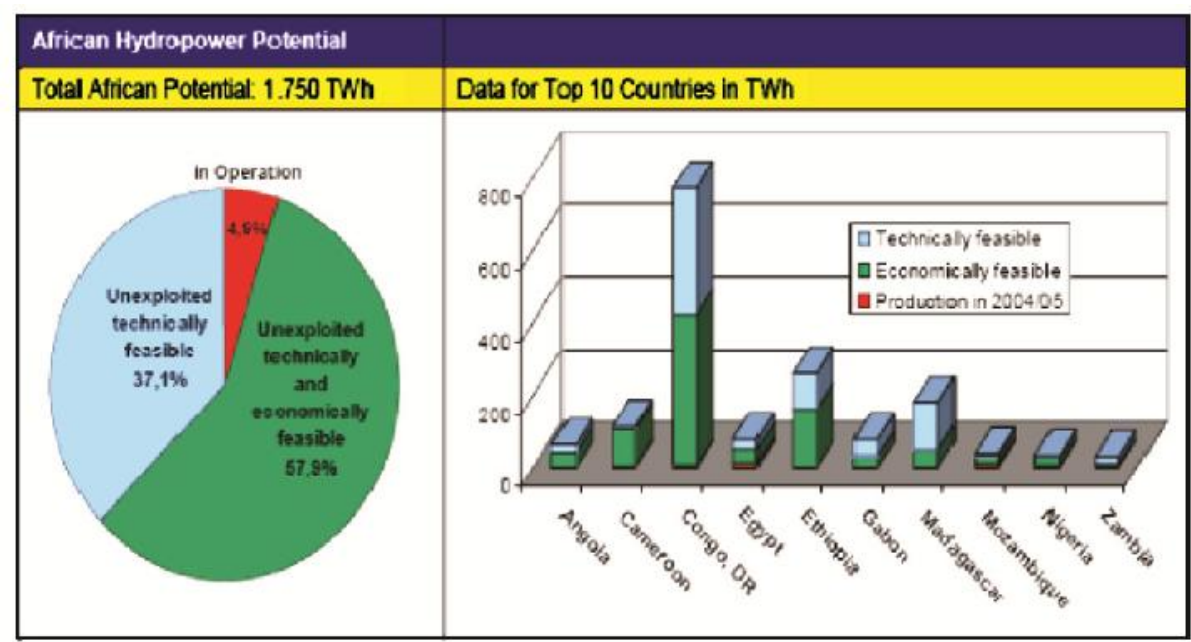

Figure 4. African Hydropower Potential Sources: Anonymous (a) 2008

\section{Hydropower Potential in Southern Africa}

Africa has the biggest hydropower potentials in the world with a total installed capacity of $21000 \mathrm{MW}, 90 \%$ of which are concentrated in eight countries (D.R Congo, Egypt, Gabon, Ethiopia, Nigeria, Zambia, Madagascar, and Mozambique). Controversially it is also the least exploited potential in the world [Anonymous (a) 2008]. The DRC itself harbors the highest potential (Fig. 4) which can satisfy the demand for both central and southern African countries with Mozambique being the second largest.

In fact, the DRC through Inga hydroelectric facility currently has $1.7 \mathrm{GW}$ of electricity generating capacity [Mukheibir, 2007]. A planned $3.5 \mathrm{GW}$ expansion [Inga 3] will be coupled with the rehabilitation of Inga 1 and 2 [Hayes 2005; Poggiolini 2005] and, this may lead to the realization of the New Partnership for Africa's Development (NEPAD) southern Africa's interconnection major plan (Fig 5) which includes importing from Inga Falls a potential of 40GW from the DRC [Mukheibir, 2007] to supply the need of the sub region.

The Mozambican dam Cahora-Bassa located on the Zambezi River downstream has a potential for $1300 \mathrm{MW}$ and an annual mean generation of $11 \mathrm{TWh}$ [Mukheibir 2007]. Installed capacity of $1300 \mathrm{MWe}$ at a plant factor of $64 \%$ provides $7288 \mathrm{GWh} /$ year [NER 2004]. Located in two different climatic regions, these dams are likely to be strongly hit by predicted climate change impacts [Harrison et al.2000; Atushi, 2007, Mukheibir, 2007] on the entire southern African region. 


\section{Climate Change Impacts in Hydropower in Southern Africa}

Hydropower energy constitutes the most widely available clean energy [Whittington and Gundry, 1998], and the most reliable source of energy utilized in the world. Hydropower is an attractive energy source as it is renewable with minimal operational emissions of greenhouse gases [Anonymous (a), 200; Harrison et al. 2000].

There is common ground that climate change is likely to affect hydropower globally by the expected $1.4-5^{\circ} \mathrm{C}$ temperature rise with an increase in global precipitation levels by $5-20 \%$ at the end of twenty first century depending on regions [Harrison et al, 2000; Atushi, 2007]. Although increase in precipitations could be profitable to hydropower by more running water availability, extreme events such as flood and siltration could raise the probability that hydropower may be affected. The lowering of catchment capacity due to a large amount of sediments accumulation and the decline in energy generation [Whittington and Gundry, 1998; Atushi, 2007 Mukheibir 2007; Anonymous (b) 2008] by lack of sufficient water runoff are foreseeable problems.

Climate change impacts on hydropower in southern Africa have been experienced in Kenya and Tanzania in 2000 with hydropower interruption due to severe drought [Ongeri, 2000]. The recent hydropower decline from Inga dam experienced in DRCongo in July-August 2011 [Le Potentiel $18 / 08 / 2011]$ can also account as an early warning manifestation of climate change impact on hydropower in southern Africa. On the other hand the predicted impacts of climate change in the region will not only affect hydropower production but also its transmission due to increase in temperature, evaporation and air pollutants in the atmosphere.

Intensive evaporation due to temperature increase coupled with high humidity will evolve abundant rainfall patterns that will negatively impact on the hydropower dam capacity to sustain hydroelectric supply. Since there is insufficient implementation of air pollution policy to lower anthropogenic activities on emission of greenhouse gases in the atmosphere, constant power cuts will be experienced due to pollution built up on hydropower line. At this point Dracoulides, 2007, attests that air pollution is a major criterion for the design of transmission line insulators.

In fact, air pollution has negative effects on the insulation system of power lines and this could result in the shutdown of power line. Concurrently the same author emphasizes that flashover occurs on transmission line when there is combination of condensation, light rain or fog, ash or build up which cause arcing across insulators and dips and spikes in power supplies. This weakens the insulators, and repeated arcing can cause the shutdown of the power line. Fires can also impact the insulators of power lines due to the generated ash particles. When these are combined with high humidity under foggy conditions, they form a conductive fog that can cause transmission 
network trips. This is an environmental issue that needs to be addressed for the better hydropower transmission management since Africa is known as the single largest continental source of biomass burning emissions [Roberts et al. 2008]. Solutions to avoid pollution effect on power line exist and will be presented at the end of this paper. Thus this implies that climate change impact on hydropower will dramatically affect southern Africa region in terms of regular power demand and supply. Winter heating demand may decrease due to higher air temperature but will increase summer cooling demand [Harrison et al. 2000].

Predicted sea level rise may also threaten rivers runoff such as Zambezi River due to extreme weather pattern leading to flood and excess sedimentations. In fact, historical flood regimes of the Zambezi River have been reported to be having predictable character [Beilfuss and Santos, 2001]. However in recent years substantial hydrological changes have evolved to an unpredictable character [Beilfuss et al. 2002] which, beside the above mentioned challenges to hydropower, also cause socio economic havoc in the region. Therefore any effort to ameliorate adverse hydrological changes in flooding regime must begin with an understanding of how hydrological changes must begin with an understanding of how hydrological processes have diverged over time from their historical "predictable" character and the possible causal links between hydrological changes and the social and ecological changes over the past century, but for which limited pre-impact studies are available [Beilfuss and Santos, 2001].

\section{Discussion}

Southern Africa is potentially equipped in terms of hydropower to overcome socio economic challenges through the maximization of energy production from the existing dams and further constructions such as Kafue (Zambia) and Katende (DRC) [Pers. Com]. Future strategies for energy development in southern Africa must take into account (the role of external financing and environmental impact assessment [Davidson, 1992].

Although hydropower constitutes a first choice option for the development of the sub region, it needs to be seconded in by other clean energy forms such as wind, biogas, geothermal and solar energy. In this way, these clean energy sources are likely to contribute towards mitigation of the effects of greenhouse gas emission and the global warming potential. Sub-Saharan Africa has one of the world's fastest growing populations in the world [Africa Society, 2008] which has a very low level access to the electricity, despite the continent's rich resources [Anonymous (a) 2008]. With regard to the rapid population growth it is estimated that energy demand will greatly increase in forthcoming years [Whittington and Gundry, 1998]. This implies private capital investment to maintain and generate additional 
hydropower plants [Reibsame et al. 1995] in the region, which seems to be unrealistic given some reasons detailed below.

In fact, while studying the impact on climate change on hydropower in South Africa Harrison et al. [2000] warned that international financing requires the loan repayment to be in hard currency and reduction in revenue may affect the ability to repay the hard currency debt and therefore may severely affect weak economies. This is a challenge southern African countries have to overcome since foreign capitals will be needed for hydropower investment.

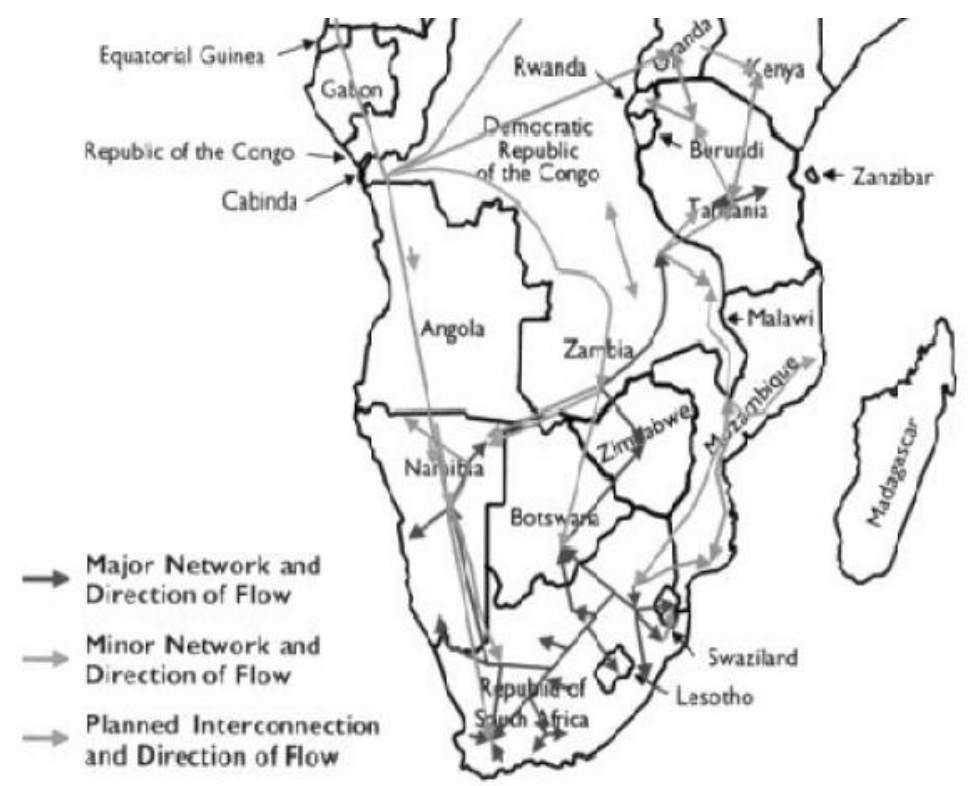

Figure 5. Existing and planned Africa connector map Source: NER 2003, citing Eskom

The viability of such projects reside on the capacity of the regional governments to better manage a number of hurdles such as technical problems including insufficient transmission capacity of Inga plants and line losses over long distances [Kenny \& Howells, 2001]. Nevertheless one of the most critical issues for energy production in southern Africa resides in regional and internal conflicts. For example a river basin shared by several nations with competition for a limited water resource may trigger more conflicts due to reduced stream flow [IPCC 2001]. Subsequently environmental options for the management of Rivers and Dams are not ensured. This is the case in the DRC where the paucity of environmental data [EC CEP, 2005] does not facilitate research on hydrological or geomorphological trends of the River Congo. 
Regarding the Congo River one must note that its position on the either side of the Equator allows its runoff to flow constantly throughout the year. When it is dry in the south of the Equator much water is poured into from adjacent rivers located north of the Equator. However as we highlighted, early research is needed to assess the correctness of this hypothesis.

In the perspective of clean energy strategy and adaptation measures to climate change, it is worth to acknowledge that alternative energy technologies such as biogas energy [through anaerobic waste digestion], solar energy, wind energy as well as geothermal energy constitute suitable energy sources that need to be promoted for both small and medium scales use in rural and peri-urban areas over the continent. Although technology transfer remains a significant challenge that impede African development appropriate technology on energy production can moderately compensate hydropower deficit due climate change impacts and consequently contribute to greenhouse gas emission reduction.

\section{Conclusion and Suggestions}

Hydropower energy constitutes a reliable, clean and appropriate source of energy for southern Africa given the remarkable potential it harbours in terms of water availability through the Congo and Zambezi Rivers. However these southern African giant hydropower sources encounter serious challenges due to predicted climate change impacts that need to be addressed and scrutinized on the bid to attain the Millennium Development Goals. More recently evidences of these impacts are being experienced at Inga dam (DRC) and at Cahora-Bassa dam in terms of shortage of water and sediments accumulation due to regular flood. It is assumed that climatic extreme events are likely to exacerbate the situation if adequate environmental management measures are not effectively implemented.

Hydropower has a great role to play in solving energy needs in the region by driving industrial growth and improving the quality of life of urban and rural populations. Notwithstanding the above strong actions are needed from both governments and civil societies to tackle the problem of good governance, to implement adequate environmental management plan for mitigating the impact of climate change on hydropower facilities. The implementation of air quality management plan throughout the region can help to hamper air pollution due to biomass burning and emission from industries and motor vehicles. Further studies including hydrological and climatological data collection and analysis for the past fifty years on both Inga and Cahora-Bassa basin may lead to modeling and adapting the trends of climate change impacts on hydropower in the sub region. 


\section{References}

1. Africa Society [2008]. Addressing Environmental Problems in Africa. Published by The Africa Society - March 2008. 7pages http://www.africasummit.org/publications/Environment.pdf. Accessed $18708 / 2011$.

2. Anonymous (a) [2008] Hydropower resource and assessment, Ministerial Conference on water for Agriculture and Energy in Africa: The challenge of climate change Sirte, Libyan Arab Jamahiriya, 15-17 December 2008.

3. Anonymous (b) [2008] Addressing Environmental Problems in Africa. The Africa Society, March 2008, 7pages http://www.africasummit.org/publications/Environment.pdf. Accessed $18 / 08 / 2011$

4. Anonymous [2011] Hydropower for sustainable Development, African experts conference on sustainable development in Africa, 31 March -1April 2011, Addis Ababa, Ethiopia.

5. APF [2007] Climate change and Africa. 8 meeting of the Africa Parternaship Forum 22-23 May 2007, Berlin, Germany, 28p.

6. Atsushi I., [2007] "Estimating Global Climate Change Impacts on Hydropower Projects: Applications in India Sri Lanka and Vietnam" Policy Research Working Paper 4344, The World Bank, Sustainable Development Network Finance, Economics, and Urban Development Department. Climate Change and Hydroelectric Resources, IEE

7. Engineering Science \& Technology, Journal. 1- 4pp.

8. Beilfuss, R. and Santos D. [2011] Patterns of hydrological change in the Zambezi Delta, Mozambique, Working paper \#2. Programme for the sustainable management of Cahora Bassa dam and the lower Zambezivalley. http : // files : gorongosa . net / filestore / 348 patterns hydrological_change_zambezi_delta.pdf Acessed 22/08/2011.

9. Beilfuss, R., A., Chilundo, A. Isaacman, W. Mulwafu, [2002], The impact of hydrological changes on impact of hydrological changes on subsitance production system and sociocultural values in the lower Zambezi Valley, Working paper \#6. Programme for the sustainable management of Cahora Bassa dam and the lower Zambezi Vallley. http://files:gorongosa.net/filestore/368-sociocultural_impact zambezi hydrological changes.pdf. Accessed 22/08/2011.

10. Davidson O. R. [1992] Annu. Rev. Energy Environ. 1992. 17:359-403

11. Dracoulides D.A [2007]. Air pollution effect on power lines scoping report, June 2007 - Report No TWPL07-R01

12. EC Country Environmental Profile (CEP) for DRC, 2005; Etude "Profil Environnemental (PEP) de la République Democratique du Congo. Rapport Provisoire, Octobre 2005.

13. Roe G. [2006]. "In defense of Milankovitch". Geophysical Research Letters 33: L24703, doi:10.1029/2006GL027817.

14. Feldman, T.S. [1993] "The Ancient Climate in theEighteenth and Early Nineteenth Century." In Scienceand Nature. Essays in the History of the EnvironmentalSciences, edited by Michael Shortland. Oxford: British Society for the History of Science.

15. Free, M., and A. Robock [1999] Global warming in the context of the Little Ice Äge, J. Geophys. Res., 104, 19,057-19,070.

16. Folland C K. Thomas R. Karl and M. Jim Salinger,[2002] Met Office Hadley Centre, Bracknell, UK National Climate Data Center, Asheville, USA

17. Harrison, G.P, H.W. Whittington, and S.W. Gundry [2000] Hydropower impacts and climate change. http://www.eng.ed.ac.uk/ gph/ publications/GPHUpec98.pdf. Accessed 18/08/2011 
18. Hayes, R. [2005]. Inga set to fly at last. African Energy Journal ,17 (5): 69.

19. Hays, J.D, J. Imbrie, and N.J. Shackleton, [1976], "Variations in the Earth's Orbit: Pacemaker of the Ice Ages," Science, 194, no. 4270, 1121-1132

20. Houghton, J. T., Y. Ding, D. J. Griggs, M. Noguer, P. J. van der Linden, X. Dai, K. Maskell, and C. A. Johnson [2001].

21. Eds., Climate Change 2001: The Scientific Basis, Contribution of Working- 18 -Group I to the Third Assessment Report of the Intergovernmental Panel on Climate Change, Cambridge Univ. Press, Cambridge,UK, 881 pp., 2001.

22. http://climate.nasa.gov/evidence/ graphic co2 graphic

23. IPCC [2001] Climate Change 2001: Impacts, adaptation and vulnerability. Contribution of Working Group II to J J McCarthy, O F Canziania, N A Leary, D J Dokken and K S White. Cambridge, Cambridge University Press for Intergovernmental Panel on Climate Change.

24. Jones, P. D., M. New, D. E. Parker, S. Martin, and I. G. Rigor, Surface air temperature and its changes over the past 150 years, Rev. Geophys., 37, 173-199, 1999.

25. Kenny, A \& Howells, M [2001]. Energy futures: trends and options for the world and for South Africa, with emphasis on the generation of electricity. Energy Management, News June. 7 (2): 10-17.

26. Le potential. Daily Newspaper. DRC /Kinshasa 18/08/2011

27. Mlambo-Ngcuka, P. 2003. Budget vote speech by Minister of Minerals and Energy, Ms. Phumzile Mlambo-Ngcuka. Minerals and energy: a catalyst in pushing back frontiers of poverty. Cape Town, Parliament. 5 May 2003.

28. Mukheibir [2007] Possible climate change impacts on large hydroelectricity schemes in Southern Africa Energy Research Centre, University of Cape Town. Vol 18 No 1

29. NER (National Electricity Regulator Bill) 2004. National Integrated Resource Plan 2 (NIRP2) 2003/4. Pretoria, 8p.

30. Ongeri, J 2000. Drought stricken Tanzania rations electricity.Afrol News. November.

31. Poggiolini, D 2005. On route to an African power highway. African Energy 7(6): 6-11.

32. Reibsame, W.E., Strzepek, K.M., Wescoat Jr., J.L.,Perritt, R., Gaile, G.L., Jacobs, J., Leichenko, R.,Magadza, C., Phien, H..' Urbiztondo, B.J.,Restrepo, P., Rose, W.R., Saleh, M., Ti, L.H.,Tucci, C. \& Yates, D. [1995] Complex River Basins. InStrzepek, K.M. \& Smith, J.B. (Eds.), As Climate Changes: International Impacts and Implications, Cambridge University Press, pp. 57-91.

33. Roberts,G., M. J. Wooster, and E. Lagoudakis (2008) Annual and diurnal African biomass burning temporal dynamics, Biogeosciences Discuss., 5 , 3623-3663, 2008

34. Robock, A., and C. Oppenheimer, [2003] Eds., Volcanism and the Earth's Atmosphere, Geophysical Monograph 139, (American Geophysical Union, Washington, DC), 360 pp., 2003.

35. Tyson PD and RA Preston-Whyte (2000). The weather and climate of Sothern Africa. 2nd edition, Oxford, University Press, Cape town, South Africa. 396p.

36. Whittington, H.W. \& Gundry, S.W.: [1998] Global Climate change and hydroelectric resources. Engineering science andeducation journal February 1998, pp 29-34. 